\title{
THE EFFECT OF SOMATOSTATIN COMBINED WITH OMEPRAZOLE ON PATIENTS WITH SEVERE ACUTE PANCREATITIS
}

\author{
JIANHUA HONG ${ }^{1 \#}$, JINYAN MI ${ }^{2 \# *}$ \\ ${ }^{1}$ Department of Digestive Internal Medicine, Tonglu First people's Hospital, Tonglu, Hangzhou, 311500, China \\ ${ }^{2}$ Orthopedic Aftercare Comprehensive Ward, Tonglu Hospital of Traditional Chinese Medicine, Tonglu, Hangzhou, 311500 , \\ China
}

*corresponding author: mijinyanhz@163.com

\#Authors with equal contribution.

Manuscript received: May 2020

\begin{abstract}
This study aimed to investigate the effects of somatostatin (SST) combined with omeprazole (OMZ) on patients with severe acute pancreatitis (SAP). Ninety-eight SAP patients were randomly divided into two groups (control group and experimental group). The control group received conventional SAP treatment, and the experimental group received conventional and SSTOMZ treatment for two weeks. The differences in serum levels of various indicators and biomarkers between the two groups on admission and after two weeks of treatment were compared. The results showed that after two weeks of treatment, in the experimental group the systemic inflammation and oxidative stress were inhibited, protecting the intestinal mucosal barrier function and regulating the gastrointestinal hormones and improve the therapeutic effect of standard SAP treatment with a decrease in the occurrence of adverse reactions.
\end{abstract}

\section{Rezumat}

Studiul a avut ca scop investigarea efectelor asocierii somatostatinei (SST) cu omeprazolul (OMZ) la pacienți cu pancreatită acută severă (SAP). Nouăzeci şi opt de pacienți cu SAP au fost împărțiți în două grupuri (grupul control și grupul experimental). Grupul control a primit tratament SAP convențional, iar grupul experimental a primit tratament convențional și SST-OMZ timp de două săptămâni. Au fost comparate nivelurile serice ale diferiților indicatori și biomarkeri între cele două grupuri, la internare şi după două săptămâni de tratament. Rezultatele au arătat că după două săptămâni de tratament, în grupul experimental, inflamația sistemică și stresul oxidativ au fost inhibate. Efectul protector asupra funcției de barieră a mucoasei intestinale a fost semnificativ, nivelul hormonilor gastrointestinali a fost îmbunătățit, iar tratamentul standard SAP a înregistrat o scădere a incidenței reacțiilor adverse.

Keywords: somatostatin, omeprazole, severe pancreatitis, intestinal mucosal barrier function, inflammation

\section{Introduction}

Acute pancreatitis (AP) is a gastroenterological inflammatory disease caused by oedema, poor digestion, haemorrhage and necrosis of the pancreatic tissue determined by the activated pancreatin in the pancreas [1]. The clinical manifestations of the disease are diverse, such as acute upper abdominal pain, fever, nausea, emesis and increased blood pancreatin [2]. Somatostatin (SST) is a growth hormone inhibitory peptide that can enhance the immune function of patients and inhibit the secretion of pancreatin [3]. The development of pancreatitis leads to the increase of SST receptors, so the administration of SST can bind to these receptors and determine the inhibition of cyclic adenosine monophosphate (cAMP) synthesis and pancreatic exocrine secretion [4]. Besides, SST can also reduce the secretion of pancreatic juice and pancreatin by inhibiting the excitement of the vagus nerve and reducing blood flow, thereby reducing the inflammatory response [5]. Omeprazole (OMZ) is a proton pump inhibitor that selectively acts on gastric mucosal parietal cells to inhibit the activity of $\mathrm{H}^{+}$$\mathrm{K}^{+}$-ATPase on the secretory microtubules found in the apical membrane of gastric parietal cells and the tubular vesicles in the cytoplasm leading to an inhibition of gastric acid secretion [6]. Moreover, it can also inhibit the secretion of pepsin, which has a partial improvement effect on gastric mucosal blood flow, having a fast onset with no significant effect on arterial blood pressure, oxygen partial pressure, carbon dioxide partial pressure, and body temperature [7]. Severe acute pancreatitis (SAP) treatment is focused mainly on the inhibition of pancreatic secretion, inflammation relief and improvement of gastrointestinal motility. In this study, we aimed to evaluate the efficacy of the SST and $\mathrm{OMZ}$ combination in the treatment of SAP.

\section{Materials and Methods}

\section{Patients}

A total of 96 SAP patients who were admitted to the Tonglu First people's Hospital, China, from October 2018 to February 2020 were selected. There were 45 
males and 51 females with the age between 32 and 68 years old. All patients had varying degrees of increased blood and urine amylase, accompanied by persistent abdominal pain. The exclusion criteria: (1) acute intestinal obstruction and acute enteritis; (2) digestive ulcers; (3) malignant tumours; (4) severe heart and lung insufficiency; (5) severe liver and kidney insufficiency; (6) other pancreatic diseases. The study protocol was approved by the Ethics Committee of Tonglu First people's Hospital, China, and the patients or the family members signed the written informed consent form.

\section{Treatment}

The patients were randomly divided into the experimental group and the control group. There were 48 cases in the experimental group, including 22 males and 26 females, aged from 36 to 65 years old, with onset time $3 \mathrm{~h}$ to $3 \mathrm{~d}$ (an average of $(1.07 \pm 0.15)$ days). There were 48 cases in the control group, including 23 males and 25 females, aged from 32 to 68 years old, with onset time $4 \mathrm{~h}$ to $3 \mathrm{~d}$ (an average of $(1.09 \pm 0.16)$ days).

Both groups of patients received conventional treatment, including continuous gastrointestinal decompression, infection prevention, pain relief, maintenance of acidbase balance, nutritional support, and the reduction of gastric juice and pancreatic juice secretion. The experimental group also received $3 \mathrm{mg}$ intravenous SST (Wuhan Humanwell Pharmaceutical Co., Ltd., China) and $40 \mathrm{mg}$ intravenous OMZ (Jiangsu Aosaikang Pharmaceutical Co., Ltd., China) once per day for seven days and then for another 7 days twice per day. Clinical and biochemical assays

The clinical efficacy was evaluated based on the Chinese guidelines for the management of acute pancreatitis (Shanghai 2013) as follows: significantly effective: after three days of treatment the clinical symptoms and signs disappeared, and relevant laboratory indicators returned to normal; effective: after 4 - 7 days of treatment, clinical symptoms and signs disappeared and relevant laboratory indicators returned to normal; ineffective: after one week of treatment, the clinical symptoms and signs had not been significantly improved or even worsened, and the relevant laboratory indicators had not returned to normal.

Clinical symptoms improvement time: the disappearance time of the clinical manifestations of the disease such as fever, abdominal pain, nausea, emesis and abdominal distension and tenderness.

Gastrointestinal hormones evaluation: $4 \mathrm{~mL}$ of venous blood was collected from the patients' hands before the treatment and after two weeks of treatment. The venous blood was centrifuged at $3000 \mathrm{r} / \mathrm{min}$ for 10 min, and the Hitachi 7600 automatic biochemical analyser was used to detect serum motilin (MTL), gastrin (GAS) and the vasoactive intestinal peptide (VIP). Enzyme-linked immunosorbent assay (ELISA) method was used for detection and all the kits and reagents were purchased from Beijing Jingmei Bioengineering Co., Ltd., China.

Oxidative stress markers evaluation: Immunofluorescence quantitative kit (Beijing Ouhe Technology Co., Ltd., China) was used to detect the content of oxidative stress markers in serum samples which included: malondialdehyde (MDA), lipid hydrogen peroxide (LHP), and advanced oxidation protein products (AOPPs), and the antioxidant indicators: superoxide dismutase (SOD), glutathione peroxidase (GSH-Px) and catalase (CAT).

Inflammatory factors: the serum collected as above was used to detect the interleukin-1 $\beta$ (IL-1 $\beta$ ), interleukin-8 (IL-8), interleukin-18 (IL-18), hypersensitivity $\mathrm{C}$ reaction Protein (hs-CRP), and TNF- $\alpha$ in the serum. The methods used for detection were ELISA and all the kits and reagents were purchased from Wuhan Moshake Biotechnology Co., Ltd., China.

Chemokines evaluation: we evaluated the monocyte chemotactic factor protein 1 (MCP-1), fractalkine (FKN) and neutrophil chemotactic factor (CINC) levels. The methods used for detection were ELISA and all the kits and reagents were purchase from Wuhan Moshake Biotechnology Co., Ltd., China.

Intestinal mucosal barrier function assays: the serum collected as above was used to detect the levels of serum endotoxin (ET), D-lactic acid (DLA), diamine oxidase (DAO), fatty acid-binding protein (FABP), amylase (AMY) using the Hitachi 7600 automatic biochemical using reagent purchased from Hitachi, Japan. Adverse reactions evaluation: the incidences of the pancreatic pseudocyst, acute distress syndrome, acute heart failure, gastrointestinal haemorrhage, and other adverse reactions during the treatment period of the two groups were statistically analysed.

Statistical methods

All data were analysed and processed by SPSS 22.0 statistical software (IBM, USA), and the data were compared by Student's t-test. A value of $p<0.05$ indicated that the difference was statistically significant.

\section{Results and Discussion}

\section{Clinical effect}

In the experimental group, the treatment was markedly effective in 25 cases, effective in 19 cases and ineffective in 4 cases. On the contrary, in the control group, the treatment was markedly effective in 19 cases, effective in 18 cases and ineffective in 11 cases. The effective rate was $91.67 \%$ (44/48) in the experimental group, which was markedly higher than $77.08 \%(37 / 48)$ in the control group $(p<0.05)$. The disappearance time of clinical symptoms and signs such as fever, abdominal pain, nausea, emesis, abdominal distension and abdominal tenderness in the experimental group was significantly shorter than that in the control group ( $\mathrm{p}<0.05)$. The data are shown in Table I. Gastrointestinal hormones 
Before treatment, were no statistically significant differences between serum levels of MTL, GAS and VIP in the two groups of patients $(p>0.05)$. After two weeks of treatment, the serum MTL level significantly increased compared with the levels before treatment in both groups, while the GAS and VIP levels

significantly decreased compared with the levels before treatment in both groups $(\mathrm{p}<0.05, \mathrm{p}<0.01)$. Compared with the control group after treatment, the serum MTL level was significantly increased, while the serum level of GAS and VIP were significantly decreased in the experimental group $(\mathrm{p}<0.05)$ (Figure 1).

Table I

Time of disappearance of clinical symptoms (days)

\begin{tabular}{lccccc}
\hline \multicolumn{1}{c}{ Group } & Fever & $\begin{array}{c}\text { Nausea and } \\
\text { emesis }\end{array}$ & $\begin{array}{c}\text { Abdominal } \\
\text { pain }\end{array}$ & $\begin{array}{c}\text { Abdominal } \\
\text { distension }\end{array}$ & $\begin{array}{c}\text { Abdominal } \\
\text { tenderness }\end{array}$ \\
\hline The experimental group & $2.15 \pm 0.38^{*}$ & $1.69 \pm 0.39^{*}$ & $2.16 \pm 0.52^{*}$ & $2.38 \pm 0.49^{*}$ & $2.33 \pm 0.31^{*}$ \\
The control group & $4.63 \pm 0.73$ & $4.52 \pm 0.58$ & $4.91 \pm 0.80$ & $4.27 \pm 0.46$ & $4.06 \pm 0.51$ \\
\hline compared with the control group & & & & &
\end{tabular}

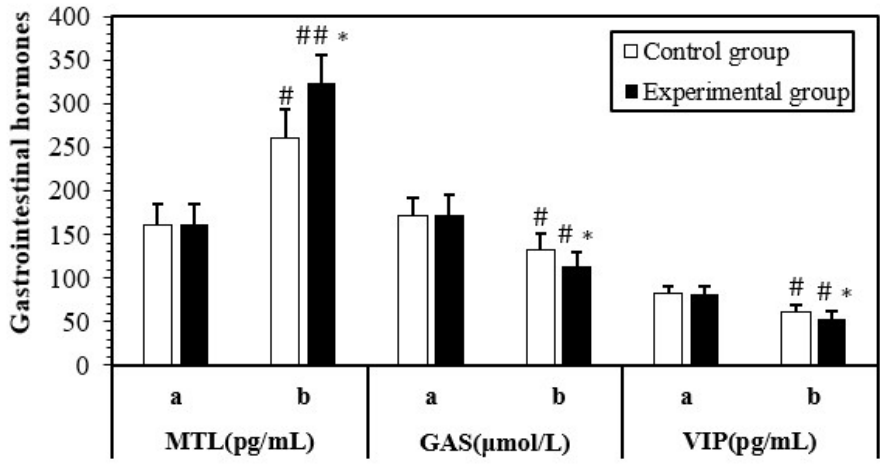

Figure 1.

Gastrointestinal hormone indexes in the two studied groups $\mathrm{a}$ - the levels at baseline, before treatment; $\mathrm{b}$ - the levels after 2 weeks of treatment; ${ }^{\#}<0.05,{ }^{\#} \mathrm{p}<0.01$ the values after treatment $v s$. the values on admission within the group; ${ }^{*} \mathrm{p}<0.05$ compared with the control group at the same time point

Oxidative stress biomarkers

At the time of admission, were no significant differences in the serum levels of MDA, LHP, AOPPs, SOD, GSHPx and CAT between the two groups $(\mathrm{p}>0.05)$. After two weeks of treatment, it was observed a decrease in the levels of oxidation indicators including MDA, LHP and AOPPs in both groups and an increase in the levels of antioxidant indicators including SOD,
GSH-Px and CAT $(\mathrm{p}<0.05)$. After two weeks of treatment, the serum levels of oxidation indicators MDA, LHP and AOPPs significantly increased compared with the levels before treatment in both groups, while the levels of antioxidant indicators SOD, GSH-Px and CAT significantly increased compared with the levels before treatment in both groups $(\mathrm{p}<0.05)$.

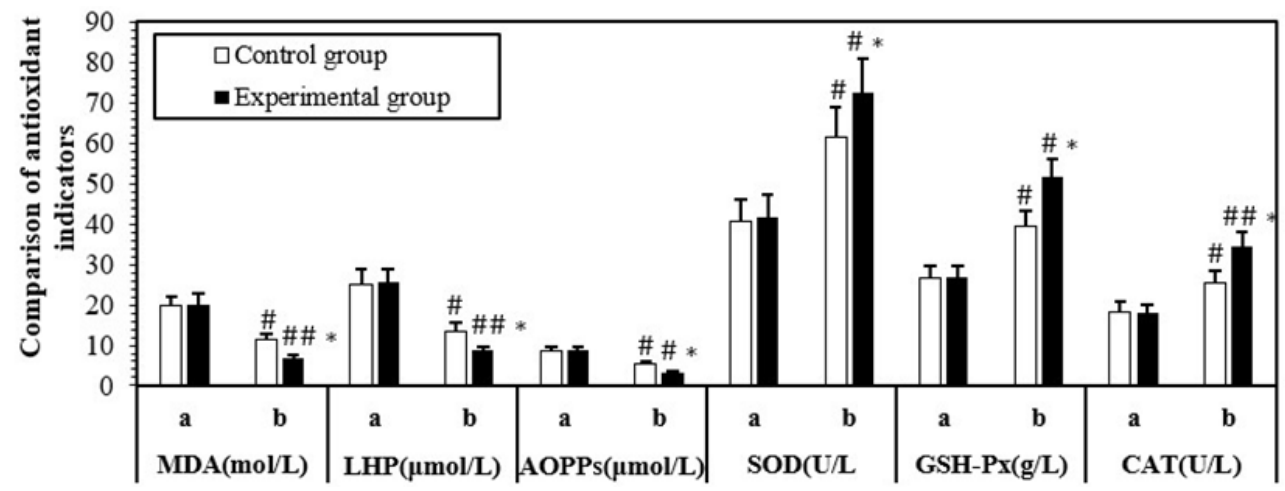

Figure 2.

The levels of antioxidant indexes in serum samples before and after the treatment $\mathrm{a}$ - the levels at baseline, before treatment; $\mathrm{b}$ - the levels after 2 weeks of treatment; ${ }^{\#} \mathrm{p}<0.05,{ }^{\# \#} \mathrm{p}<0.01$ the values after treatment $v s$. the values on admission within the group; * $p<0.05$ compared with the control group at the same time point

Compared with the control group after treatment, serum levels of oxidation indicators MDA, LHP and AOPPs were significantly decreased, while the serum levels of antioxidant indicators SOD, GSH-Px and CAT were significantly increased in the experimental group $(\mathrm{p}<$ 0.05) (Figure 2). 
Inflammatory factors

There was no significant difference in the levels of serum IL-1 $\beta$, IL-8, IL-18, hs-CRP and TNF- $\alpha$ on admission between the two groups ( $p>0.05)$. After two weeks of treatment, the levels of serum IL-1 $\beta$, IL-8, IL-18, hs-CRP and TNF- $\alpha$ in the two groups were significantly decreased compared with the levels on admission ( $p<0.05, p<0.01)$. The treatment received by the experimental group significantly decreased the serum levels of IL- $1 \beta$, IL- 8 , IL- 18 , hs-CRP and TNF- $\alpha$ compared with the control group after two weeks $(\mathrm{p}<$ 0.05) (Figure 3).

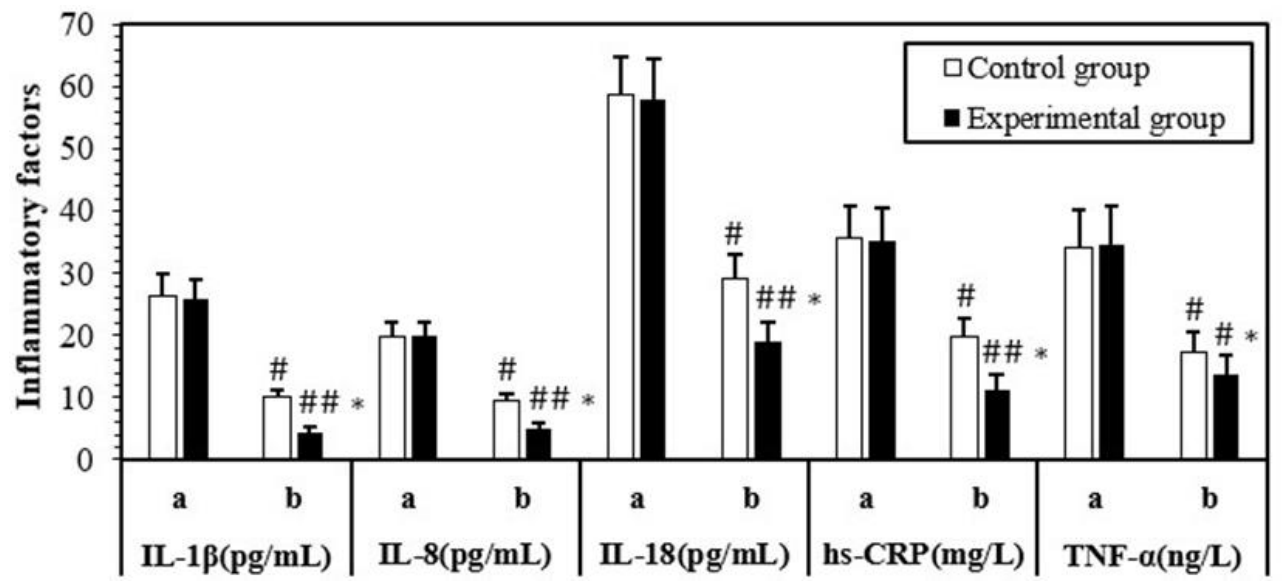

Figure 3.

The levels of serum IL-1 $\beta$, IL-8, IL-18 and hs-CRP before and after the treatment $\mathrm{a}$ - the levels at baseline, before treatment; $b$ - the levels after 2 weeks of treatment; ${ }^{\#}<<0.05,{ }^{\# \#} p<0.01$ the values after treatment $v s$. the values on admission within the group; ${ }^{*} \mathrm{p}<0.05$ compared with the control group at the same time point

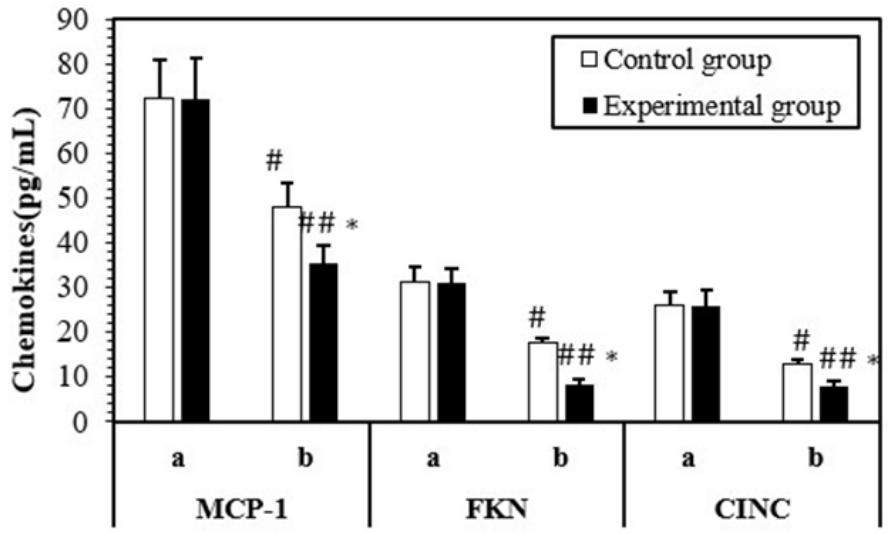

Figure 4.

The levels of MCP-1, FKN and CINC in serum before and after the treatment $\mathrm{a}$ - the levels at baseline, before treatment; $\mathrm{b}$ - the levels after 2 weeks of treatment; ${ }^{\#}<0.05,{ }^{\#} \mathrm{p}<0.01$ the values after treatment $v s$. the values on admission within the group; ${ }^{*} p<0.05$ compared with the control group at the same time point

Chemokines assay

There was no significant difference in serum MCP-1, FKN and CINC levels on admission between the two groups ( $p>0.05)$. After two weeks of treatment, the serum MCP-1, FKN and CINC levels significantly decreased compared with the levels before treatment in both groups $(\mathrm{p}<0.05, \mathrm{p}<0.01)$. Compared with the control group after treatment, the serum MCP-1, FKN and CINC levels were significantly decreased in the experimental group $(\mathrm{p}<0.05)$ (Figure 4).
Indicators of intestinal mucosal barrier function There was no significant difference in serum levels of DLA, DAO, ET and FABP between the two groups on admission ( $p>0.05)$. After two weeks of treatment, the levels of serum DLA, DAO, ET and FABP were significantly decreased, compared with the levels on admission $(\mathrm{p}<0.05, \mathrm{p}<0.01)$. Moreover, the serum DLA, DAO, ET and FABP levels were significantly decreased in the experimental group compared with the control group after two weeks of treatment ( $\mathrm{p}$ 0.05) (Figure 5). 


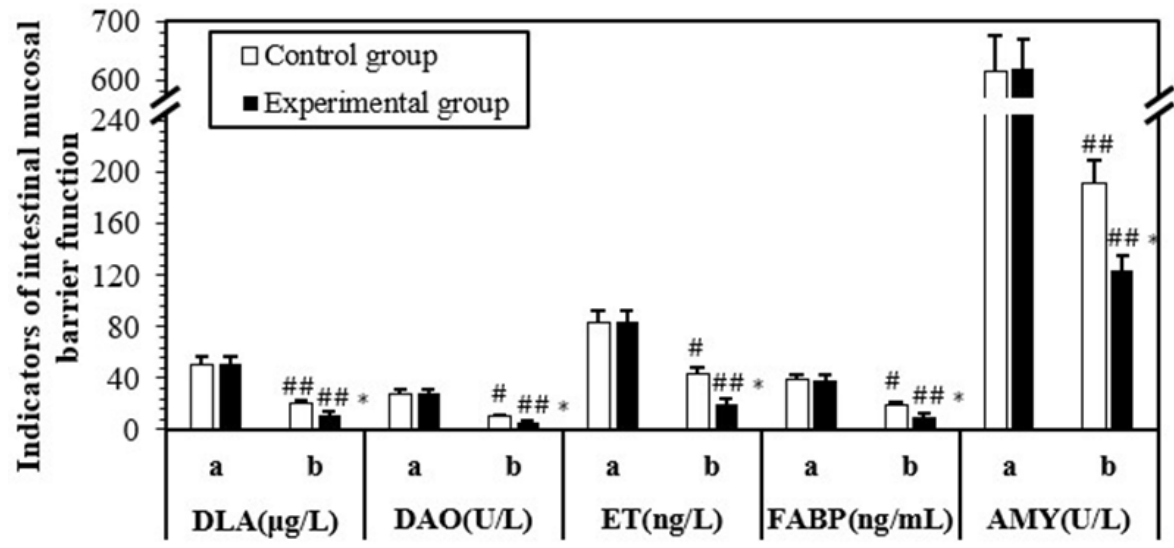

Figure 5.

The levels of DLA, DAO, ET and FABP in serum before and after the treatment

$\mathrm{a}$ - the levels at baseline, before treatment; $\mathrm{b}$ - the levels after 2 weeks of treatment; ${ }^{\#} \mathrm{p}<0.05,{ }^{\# \#} \mathrm{p}<0.01$ the values after treatment $v s$. the values on admission within the group; $* \mathrm{p}<0.05$ compared with the control group at the same time point

\section{Adverse reactions}

The complications in the experimental group $(8.33 \%$ (4/48)) were significantly decreased compared with the control group $(31.25 \%(15 / 48))$. The main complications observed in the control group were gastrointestinal haemorrhage (10.42\%), pancreatic pseudocysts (8.33\%), acute distress syndrome $(6.25 \%)$ and acute heart failure $(6.25 \%)$. In the experimental group, there were observed only gastrointestinal haemorrhage $(4.17 \%)$ and pancreatic pseudocysts $(4.17 \%)$ (Table II).

Table II

Adverse Reaction observed in the two groups during the 2 weeks of treatment

\begin{tabular}{lcc}
\hline & The control group & The experimental group \\
\hline Pancreatic pseudocyst & $4(8.33)$ & $2(4.17)^{*}$ \\
Acute distress syndrome & $3(6.25)$ & $0(0.00)^{* *}$ \\
Acute heart failure & $3(6.25)$ & $0(0.00)^{* *}$ \\
Gastrointestinal haemorrhage & $5(10.42)$ & $2(4.17)^{*}$ \\
Summation & $15(31.25)$ & $4(8.33)^{* *}$ \\
\hline
\end{tabular}

${ }^{*} \mathrm{p}<0.05,{ }^{* *} \mathrm{p}<0.01$ compared with the control group at the same time point

OMZ can specifically inhibit basic gastric acid and the gastric acid secretion induced by stress conditions and can effectively prevent the pancreatic hypersecretion state [8]. It is mostly used for the treatment of light AP. SST is a drug that can effectively inhibit pancreatic digestive enzymes and pancreatic juice secretion, blocks the pathological basis of inflammation, promotes the repair of pancreatic tissue cells [9] and exerts antioxidant effects [10]. Gastrointestinal hormones are a class of small-molecule active substances secreted by related cells including gastrointestinal mucosal cells and pancreatic endocrine cells and their levels influence the normal gastrointestinal functional status [11]. GAS can promote gastro-contraction and enhance gastrointestinal motility. MTL and VIP are gastrointestinal inhibitory hormones, which can cause gastric reflex relaxation [12].

In our study, the combination of OMZ and SST added to the conventional significantly increased MTL levels and significantly decreased GAS and VIP levels along with the significant decrease of oxidative stress by keeping the oxidative/antioxidative balance.

The oxidative stress response plays a very crucial role in the occurrence and development of SAP. The self-digestion of the tissue leads to an imbalance of oxidation/antioxidation in the body [13]. During this process, large quantities of oxygen free radicals are produced and damage the vascular endothelium directly, resulting in vasoconstriction and ischemia, and irreversible necrosis in organs $[14,15]$. Therefore, detecting the levels of oxidation and antioxidant factors in the body can objectively reflect the severity of the patient's condition and evaluate the effectiveness of clinical treatment programs $[16,17]$. The results of the experiments showed that compared with the control group, the experimental group had lower levels of oxidation biomarkers, including MDA, LHP and AOPPs in the serum after treatment, and higher levels of antioxidant biomarkers including SOD, GSH-Px and CAT. The results revealed that the addition of SST can effectively keep the balance oxidative/antioxidative of SAP patients and inhibit the degree of oxidative stress in the body, which is one of the key links to optimize the condition.

The cascade amplification activation of the systemic inflammatory response is a decisive change in SAP patients. The inflammatory cascade caused by multiple inflammatory factors is responsible for the stasis of the patient's condition and the appearance of dysfunctions in multiple important organs [2]. In our 
study, the level of each inflammatory factor in the serum of the experimental group after treatment was lower than that in the control group. This supports the finding the inflammatory cascade was inhibited by adding OMZ and SST to the conventional treatment compared with the conventional treatment alone.

The self-digestion of the pancreas leads to local tissue damage in SAP patients and activates local white blood cells, which promotes the secretion of multiple chemokines, and further induces the synthesis of inflammatory factors and forms a systemic inflammatory response. MCP-1 can activate and chemoattract monocytes, which can cause inflammation in the body [18]. FKN is mainly expressed on the surface of activated endothelial cells in the human body. A large amount of FKN is synthesized and secreted by SAP patients and released into the blood. It further affects chemotaxis in many cells such as neutrophils, lymphocytes, monocytes, which allows a large number of inflammatory cells to enter the inflammatory tissue $[19,20]$. CINC is expressed in neutrophils and acinar cells, and it is expressed in a large number of patients with SAP and lung injury. Besides, the expression level of FKN is positively correlated with the degree of lung injury. FKN participates in inflammation and causes lung injury $[21,22]$. The serum levels of chemokine MCP-1, FKN and CINC in the experimental group after treatment were lower than those in the control group. Our date indicate that the addition of STT can effectively inhibit the secretion of chemokines in SAP patients, and reduce the systemic inflammation of patients which is one of the objective manifestations of reducing the degree of systemic inflammation in patients.

Under pathological conditions such as SAP, the damage of the intestinal mucosal barrier can cause a series of pathological features [23]. The abnormal levels of multiple factors in the circulating blood can be regarded as reliable indicators to measure the function of the intestinal mucosal barrier. Among them, DLA is a bacterial fermentation product and is rarely absorbed by the intestine under physiological conditions. When acute ischemia occurs in the intestine, DLA enters the blood through the damaged intestinal mucosa [24]. Moreover, DAO has low activity in other tissues. When intestinal mucosal cell damage occurs, the level of DAO increases in both intestinal lumen and circulating blood [25]. ET is produced by enteric pathogens, and can also enter the circulating blood in large quantities when the intestinal mucosal function is impaired and cause toxaemia [26]. Also, when intestinal ischemia damage occurs, the permeability of intestinal epithelial cells increases and FABP enters the blood circulation through the capillaries and is detected in the peripheral blood [27]. Besides, AMY is an effective indicator for the early diagnosis of AP [28]. Related studies have shown that ET, DLA, DAO, FABP, AMY can specifically reflect the degree of damage to the intestinal mucosal barrier function
[29]. The level of intestinal mucosal barrier function indicators in the serum of the experimental group after treatment was lower than those of the control group, indicating that the addition of SST to the overall treatment can effectively protect the intestinal mucosal barrier function, which is a significant manifestation of improving the patient's final treatment outcome.

\section{Conclusions}

The addition of SST and OMZ to the SAP conventional treatment can improve the therapeutic effects and reduce the incidence of adverse reactions.

\section{Conflict of interest}

The authors declare no conflict of interest.

\section{References}

1. Vithayathil M, Chang CK, Shetty H, Stewart R, Risk of acute pancreatitis among people with severe mental illness. J Affect Disord., 2020; 263: 722-727.

2. Seon K J, Jung K H, Young-Tae B, Correlation between obesity and fever in acute pancreatitis. Pancreatology, 2018; 18(4): S98.

3. Arvanitidis D, Anagnostopoulos GK, Giannopoulos D, Pantes A, Agaritsi R, Margantinis G, Tsiakos S, Sakorafas G, Kostopoulos P, Can somatostatin prevent post-ERCP pancreatitis? Results of a randomized controlled trial. J Gastroenterol Hepatol., 2004; 19(3): 278-282.

4. Arndt J, Somatostatin for prevention of post-ERCP pancreatitis: a randomized, double-blind trial. Endoscopy, 2014; 46(10): 851-856.

5. Wang W, Shao L, Zhiyuan MA, Combined Application of Rhubarb and Somatostatin in the Ttreatment of Severe Acute Pancreatitis: A Systematic Review. Medicinal Plant, 2014; (6): 55-60.

6. Eland IA, Alvarez CH, Stricker BH, Rodríguez LA, The risk of acute pancreatitis associated with acidsuppressing drugs. Br J Clin Pharmacol., 2000; 49(5): 473-478.

7. Abdelfatah MM, Nayfe R, Nijim ALA, Agito M, Haller N, Su1688 Proton Pump Inhibitor (PPI) Does Not Prevent Post-ERCP Pancreatitis. Gastrointestinal Endoscopy, 2014; 79(5): AB367-AB367.

8. Ma ZL, Yao J, Gao RM, Impact of octreotide combined with omeprazole on gastrointestinal hormones and intestinal mucosal barrier function in patients with acute pancreatitis. World Chinese J Digestology, 2018; 26(20): 1241-1246, (available in Chinese).

9. Guo Z, Wang R, Tang C, Mo1059 Effect of Octreotide on Plasma Levels of Somatostatin Interleukin-6, and Tumor Necrosis Factor- $\alpha$ in Patients With Acute Pancreatitis: A Prospective Single-Center Randomized Controlled Trial. Gastroenterology, 2013; 144(5): S-566.

10. Li W, Shi YH, Yang RL, Cui J, Xiao Y, Wang B, Le $\mathrm{GW}$, Effect of somatostatin analog on high-fat dietinduced metabolic syndrome: involvement of reactive oxygen species. Peptides, 2010; 31(4): 625-629.

11. Juel J, Brock C, Olesen SS, Madzak A, Farmer AD, Aziz Q, Frøkjær JB, Drewes AM, Acute physiological 
and electrical accentuation of vagal tone has no effect on pain or gastrointestinal motility in chronic pancreatitis. J Pain Res., 2017; 10: 1347-1355.

12. Gong H, He Z, Tang W, Chen G, Xia Q, Huang X, Influence of NF- $\kappa \mathrm{B}$-vasoactive intestinal peptide on intestinal dysmotility in severe acute pancreatitis. $J$ Pure Appl Microbiol., 2012; 6(1): 47-52.

13. Yu QH, Zhang PX, Liu Y, Liu W, Yin N, Hyperbaric oxygen preconditioning protects the lung against acute pancreatitis induced injury via attenuating inflammation and oxidative stress in a nitric oxide dependent manner. Biochem Biophys Res Commun., 2016; 478(1): 93-100.

14. Iosif L, Lixandru D, Gaman L, Ilie M, Smeu B, Ștefan DS, Petcu L, Picu A, Constantin A, Ionescu-Tîrgovişte C, Guja C, Copăescu C, Stoian I, Oxidative stress profile and type 2 diabetes remission at 6 months after sleeve gastrectomy versus conservatory treatment. Farmacia, 2019; 67(1): 99-105.

15. Ozturk K, Tasci I, Yasar M, Akay C, Alcigir M, Vural S, Mas MR, Turker T, Saglam K, Effects of rapamycin treatment on pancreatic fibrosis, cellular apoptosis and oxidative stress in experimental chronic pancreatitis model. Acta Gastroenterol Belg., 2015; 78(1): 3-7.

16. Huang L, Jiang Y, Sun Z, Gao Z, Wang J, Zhang D, Autophagy Strengthens Intestinal Mucosal Barrier by Attenuating Oxidative Stress in Severe Acute Pancreatitis. Dig Dis Sci., 2018; 63(4): 910-919.

17. Ozturk H, Cetinkaya A, Erdogan Duzcu S, Yis OM, Ozturk H, Carvacrol reduces the severity of intestinal mucosal damage caused by intestinal ischemia Reperfusion in rats. Farmacia, 2019; 67(5): 892-898.

18. Chang CT, Tsai TY, Liao HY, Chang CM, Jheng JS, Huang WH, Chou CY, Chen CJ, Double Filtration Plasma Apheresis Shortens Hospital Admission Duration of Patients With Severe Hypertriglyceridemia-Associated Acute Pancreatitis. Pancreas, 2016; 45(4): 606-612.

19. Li F, Zhang H, Xu KY, Wei Q, Zhou GX, Role of the chemokine fractalkine in a rat model of acute necrotizing pancreatitis and the interventional effect of ulinastatin. Arch Iran Med., 2013; 16(2): 83-87.

20. Huang L, Ma J, Tang Y, Chen P, Zhang S, Zhang Y, Yuan YZ, siRNA-based targeting of fractalkine overexpression suppresses inflammation development in a severe acute pancreatitis rat model. Int $\mathrm{J} \mathrm{Mol}$ Med., 2012; 30(3): 514-520.
21. Zhang FH, Sun YH, Fan KL, Dong XB, Han N, Zhao $\mathrm{H}$, Kong L, Protective effects of heme oxygenase-1 against severe acute pancreatitis via inhibition of tumor necrosis factor- $\alpha$ and augmentation of interleukin10. BMC Gastroenterol., 2017; 17(1): 100: 1-7.

22. Wang JL, Chen Y, Song XQ, Lu ML, Zhao B, Ma L, Chen EZ, Mao EQ, Biliary tract external drainage protects against multiple organs injuries of severe acute pancreatitis rats via heme oxygenase-1 upregulation. Pancreatology, 2017; 17(2): 219-227.

23. Li Y, Wu H, Deng Y, Liao R, Xi L, Yao P, Changes of Intestinal Mucosal Barrier and Intestinal Flora in Rats with Severe Acute Pancreatitis. Sheng Wu Yi Xue Gong Cheng Xue Za Zhi, 2015; 32(2): 412-417, (available in Chinese).

24. Li XY, He C, Zhu Y, Lu NH, Role of gut microbiota on intestinal barrier function in acute pancreatitis. World J Gastroenterol., 2020; 26(18): 2187-2193.

25. Tu XH, Huang SX, Li WS, Song JX, Yang XL, Mesenchymal stem cells improve intestinal integrity during severe acute pancreatitis. Mol Med Rep., 2014; 10(4): 1813-1820.

26. Kuuliala K, Penttilä AK, Kaukonen KM, Mustonen H, Kuuliala A, Oiva J, Hämäläinen M, Moilanen E, Pettilä V, Puolakkainen P, Kylänpää L, Repo H, Signalling Profiles of Blood Leucocytes in Sepsis and in Acute Pancreatitis in Relation to Disease Severity. Scand J Immunol., 2018; 87(2): 88-98.

27. Koçak E, Akbal E, Köklü S, Adam G, Evaluation of serum L-FABP levels in patients with acute pancreatitis. Ulus Travma Acil Cerrahi Derg., 2015; 21(1): 39-43

28. Mohammad Alizadeh AH, Afzali ES, Zafar Doagoo S, Mousavi M, Mirsattari D, Shahnazi A, Zali MR, Preventive role of wire-guided cannulation to reduce hyperamylasemia and pancreatitis following endoscopic retrograde cholangiopancreatography. Diagn Ther Endosc., 2012; 2012: 821376: 1-5.

29. Li HC, Fan XJ, Chen YF, Tu JM, Pan LY, Chen T, Yin PH, Peng W, Early prediction of intestinal mucosal barrier function impairment by elevated serum procalcitonin in rats with severe acute pancreatitis. Pancreatology, 2016; 16(2): 211-217. 